\title{
A Big Bang? The Paradox of the Reception of Günter Grass's Die Blechtrommel in The Netherlands
}

\author{
Jos Joosten
}

\begin{abstract}
Die niederländische Rezeption der Blechtrommel verlief nahezu paradox. Als der Roman auf Deutsch veröffentlicht wurde, wurde er in den Niederlanden so gut wie gar nicht rezensiert; doch kurz nachdem er 1959 in Deutschland erschienen war, konnte man bereits die ersten Zeitungsartikel über Günter Grass als (literarisches) Phänomen lesen. In den Jahren danach taucht Grass' Name als bekanntester Repräsentant der jungen deutschen Literatur regelmäßig in der Presse auf, und wenig später auch mit Bezug auf seine politischen Aktivitäten - immer in Kombination mit dem Titel der Blechtrommel. Der Romantitel ist innerhalb kürzester Zeit nicht viel mehr als eine Erwähnung. Wahrscheinlich aufgrund des finanziellen Risikos sollte es noch fünf Jahre dauern, bis die niederländische Übersetzung des Romans unter dem Titel De blikken trommel veröffentlicht wurde. Diese Übersetzung wurde nur in solchen Zeitungsmeldungen kurz erwähnt, die sich mit Neuerscheinungen befassten. Fast immer standen dort nur wenige Zeilen, die wiederum kaum auf das Buch selbst (oder dessen Übersetzung) Bezug nahmen, sondern insbesondere auf den internationalen Erfolg des Buches verwiesen. Echte Rezensionen bekam Grass' Debüt also kaum. Die niederländische(n) Übersetzung(en) der Blechtrommel wurde(n) ungefähr dreißig Mal neu gedruckt. Schätzungen zufolge wurden mehrere hunderttausend Exemplare der Übersetzung verkauft. Bis heute tauchen das Buch und/oder sein Titel in der niederländischen Presse auf, und die entsprechenden Artikel bekommen ab und zu neue Impulse, z.B. durch die Verfilmung oder die Verleihung des Nobelpreises an Grass. In den Niederlanden war das Buch selbst jedoch nie Anlass für eine ernsthafte, inhaltliche Debatte über soziale, politische oder gesellschaftliche Fragen.
\end{abstract}

(C) JOS JOOSTEN, 2016 | DOI 10.1163/9789004291898_008

This is an open access chapter distributed under the terms of the CC-BY-NC License. 


\section{Die Blechtrommel and Its Reception in the Dutch Press: Collecting the Material, and the Dutch Literary Context}

Although it is a recent period, it is relatively hard to obtain a complete collection of reviews from the period 1945-1980, particularly those from the daily and weekly newspapers. Due to copyright complications and (still) unsystematic digitization, reviews from these decades are sometimes unexpectedly difficult to find. An extra complicating factor in the case of Die Blechtrommel is that the most complete Dutch database of book reviews, the 'LITEROM', does not contain reviews on foreign or translated literature. Its international counterpart, the 'Literom Wereldliteratuur', when it comes to Die Blechtrommel, contains only reviews from the last decennia. It thus has a complete overlap with the LexisNexis index, which is a full text digital index of the most important Dutch national, regional and local daily and weekly newspapers. The drawback of this collection is that it doesn't start before 1990 and is therefore not useful for investigating the early reception of Die Blechtrommel. For this period we are lucky to have Delpher [<www.delpher.nl $>$ ], the online historical newspaper database of the Dutch Royal Library in The Hague. It contains a complete searchable full text corpus of national, regional and local newspapers, and as such is priceless. Compared to only a few years ago this enormous collection of searchable texts is a real goldmine, but it still has its quantitative restriction: a rough estimation states that only $10 \%$ of all Dutch newspapers have been digitized by Delpher. ${ }^{1}$ In addition to these digital sources we have Nijhoff's index, a paper source in which texts from Dutch and Flemish weekly and monthly magazines from the greater part of the twentieth century are indexed. This index ends in 1968. Beside Delpher there are, spread across the internet, several local and regional papers throughout the country that have been digitized, and although there is a central portal where many of them are brought together, ${ }^{2}$ unfortunately they are not accessible through a single search engine. Although the amount of analysed texts therefore is far from $100 \%$ of what has been published, it is safe to consider the searched corpus as a representative sample of Dutch journals from the early 196os, with both regional and national papers, from all varieties of the political spectrum, for example, social-democrat (Het

1 On the home page, it is stated that Delpher contains "eight million pages from newspapers from The Netherlands, Dutch East Indies and Surinam, from 1618 to 1995, altogether about $10 \%$ of newspapers that were published in that period". <http://www.delpher.nl/nl/platform/ pages/collecties $>$.

$2<$ http://kranten-historisch.startpagina.nl/>. 
Vrije Volk), Roman Catholic (De Tijd / De Maasbode), communist (De Waarheid) and conservative (De Telegraaf).

The titles that are made accessible on the last mentioned web portal do, with quantitative restrictions, give a sketch of the complex situation of the Dutch press in the 1960s. At the time a completely different media environment existed, still strongly influenced by the so called 'verzuiling' (literally: pillarisation). For a long time during the 2oth century Dutch society was socially and politically divided into various ideological segments: liberal, socialist, Protestant and Roman Catholic. All of these segments had not only their own political parties and trade unions, but also their own sporting clubs, broadcasting companies and, of course, news media.

In 1960, there were 61 editorially independent newspapers in The Netherlands; in 1975, that number had been reduced to 45 titles. The number of independent newspaper companies halved in the same period to 18 companies. In 2013, these figures were further decreased. In the Netherlands, according to the Media Monitor, nowadays only ten 'core papers' still exist, and six independent newspaper companies. In the year Die Blechtrommel was published, by contrast, a relatively small town like Nijmegen had two independent newspapers (the Catholic De Gelderlander and the liberal Nijmeegs Dagblad) and also the socialist paper Het Vrije Volk had its local pages. A larger city like The Hague had three newspapers (Haagsche Courant, Haagsch Dagblad and Het Vaderland).

When we focus on the reception of recently published Dutch-language literature it becomes clear that, at the time, not only was the economic constellation different, but also the fact that the symbolic capital that newspapers wished to invest in literary criticism was clearly present. All national papers, and the vast majority of regional newspapers, had their own in-house critic, in general persons who were already otherwise active in the literary field, as author, poet or essayist.

Compared to the usual critical practice of Dutch literature, it transpires that a foreign debutant like Grass was reviewed quite differently. A small example may show this. Research on the reception of the novel De Verwondering (Astonishment) by a contemporary of Grass, the Flemish author Hugo Claus, that was published in 1963, shows that this book received about forty reviews in Dutch papers (not including the Flemish press), of which around $20 \%$ were found by consulting Delpher and Nijhoff's Index. ${ }^{3}$ The comparison isn't totally fair, of course, because Die Blechtrommel was a novel from an unknown

3 Joosten (2014). 
German debutant - but still the difference in the way Grass's novel was received is striking. ${ }^{4}$

\section{Receiving Grass: The German Original}

Compared to his present state of world fame, it is hard to imagine to what extent Günter Grass was a totally unknown stranger to Dutch critics at the end of the 1950s. The earliest trace of Die Blechtrommel in The Netherlands is in fact illustrative. In the issue of December 1959 from the literary magazine Hollands Maandblad, a list was printed of recently published literary works, entitled "In Western Europe and the United States every day 350 new books are published. We selected a few for you". ${ }^{5}$ Grass's novel was just one of the many published works, just worthy enough to be mentioned in a list instead of drowning in the ocean of published books.

There are a few more early traces of Grass detectable in The Netherlands. One of the earliest - perhaps the earliest, but quite unexpected anyway - is a review of his debut as a poet. In the Amsterdam newspaper Het Parool of March 16, 1957 the critic Adriaan Morriën wrote an article on Die Vorzüge der Windhühner. ${ }^{6}$ At the time, Morriën was an important networker in the Dutch literary system. He was a poet and translator, editor of Tirade, a prominent monthly literary magazine, and as well as working as a critic for the Amsterdam newspaper Het Parool he also wrote for the Critisch Bulletin, a monthly journal that introduced foreign literature to the Dutch public. Beside that Morriën was an advisor for Uitgeverij Van Oorschot and De Bezige Bij, two prominent Dutch publishing houses, the latter the publisher of, amongst others, Harry Mulisch and Hugo Claus.

No doubt Morriën wrote this review of Grass's poetry as a result of his personal contacts with the Gruppe 47, and the young German poet himself. He had visited post-war Germany regularly, had come to know various young German authors personally, had attended several meetings of the Gruppe 47, and thus had become well acquainted with its founder Hans Werner Richter. The review itself of Grass's poetry was in fact rather plain: "I don't want to claim that Die Vorzüge der Windhühner consists of nothing but good poems.

4 This article will be limited to the reception of Die Blechtrommel in Dutch written journalist media. The academic or essayist reception of the novel is not taken into account.

5 "In Westeuropa en de Verenigde Staten verschijnen per dag $35^{0}$ nieuwe boeken. Wij kozen er een paar voor u uit."

6 Morriën (1999a). 
This collection of poetry is a sort of run-up, the first beginning of an attempt to express personal experiences."7 In 1993 Morriën himself refers to his own review of Grass's poems in retrospect: "I reviewed Grass's collection immediately in Het Parool, whereas it was hardly noticed in Germany."

In the beginning of November 1958 Grass was awarded the Preis der Gruppe 47 for the first chapter of the unpublished manuscript of Die Blechtrommel. It was a literary fact that wasn't noticed at all in The Netherlands, except in the literary magazine Tirade of which the same Morriën was, as we saw, one of the editors. The February/March issue of Tirade opened with a translation of the prizewinning chapter: "De wijde rok." ${ }^{9}$ In the same issue an interview was published with Richter in which he was asked about the practices of the Gruppe 47 and their Preis. Both translation and interview were done by $\mathrm{H}$. Mulder, who later became known as one of the translators of Heinrich Böll's novels. He was, however, not to be the Dutch translator of the complete Blechtrommel in 1964. A peculiar detail in Dutch is the novel's title in the Tirade-version. Mulder translated it as De Speelgoedtrommel, which literally means "The toy drum".

Although the Hollands Maandblad and Tirade were influential to the extent that they were read by a group of connoisseurs - writers, literary journalists, students and academics, and other professionals from the literary field - they were not periodicals that were widespread amongst the general public.

Directly after Die Blechtrommel was issued in German, only one real review was published: in the weekly Vrij Nederland (December 26, 1959). Most notable seems to be that there are no further reviews on Grass's debut - not even by Adriaan Morriën, who certainly knew about the novel. Morriën's biographer, Rob Molin, wrote an article on Morriën's relationship with his young German peers. ${ }^{10}$ According to the biographer, Grass sent Die Blechtrommel to Morriën in Amsterdam at the end of 1959. Morriën didn't read the novel. At that moment he was struggling with a novel of his own, and even the sight of the huge volume Grass had just published depressed him, he wrote to his German friend ("Der Teufel hole dich mit deinen Roman", he writes amicably). Molin refers to a letter Grass wrote in response, with good advice and encouragement. The facsimile of the first page of Morriën's handwritten letter is printed in Molin's

Morriën (1999a) 549. "Ik wil niet beweren dat Die Vorzüge der Windhühner louter goede verzen bevat. De bundel is eerder een aanloop, een eerste begin om persoonlijke ervaringen kenbaar te maken."

$8 \quad$ Morriën (1999b) 623.

9 Grass (1960).

10 Molin (2002). 
article. The letter contains a clause that is interesting in the context of the reception of Die Blechtrommel. Morriën writes to Grass that he first wants to finish one half of his own novel before he feels certain enough to read the German's book:

Sobald ich die Hälfte fertig habe (etwa 150 Seiten, mein Buch wird nicht so dick), werde ich deine Blechtrommel in die gesicherte Hand nehmen und für die Zeitung darüber schreiben. Übersetzung für Holland wird, fürchte ich, nicht in Frage kommen, weil schon das Übersetzungshonorar für ein so kleines Sprachgebiet zu hoch wäre. Ein halbes Jahr völliger Entsagung aller anderen Arbeiten und Verlangen würde das wenigste sein, das ein Übersetzer sich leisten sollte. Dabei lesen die meisten Holländer Deutsch. ${ }^{11}$

Of course Morriën wasn't the one to make the final financial decision on whether it was worth the economic risk of publishing a Dutch translation of Die Blechtrommel or not. But it is certain that a positive recommendation coming from him would have had influence on the prominent Dutch publishers of that moment. It is remarkable that Morriën knew about the success Grass's novel had from the moment it was published. The first line of his letter to 'Lieber Günter', dated the 18th December 1959, is: "Im Börsenblatt für den deutschen Buchhandel habe ich vom Welterfolg deines Romans gelesen." But it would take almost five years before a Dutch translation of Die Blechtrommel was published.

\section{Writer Without a Book}

Although there were hardly any real reviews of the German version of Die Blechtrommel, the book soon received another sort of attention in the Dutch press, in articles that all took, more or less extensively, the success of this relatively young German debutant as a point of reference or starting point. In $D e$ Telegraaf, for instance, an article was published in December 1960, almost a year after the publication of Die Blechtrommel, that was entitled 'A literary bomb exploded in German writers' world'. Its writer, B. Roest Crollius, places the novel in a broad, German post-war context, and presents a brief overview of the tumultuous critical response to the book in Germany. His opinion on Grass's novel is very positive, and he comes to the following conclusion:

$11 \quad$ Molin (2002) 56 . 
"Germany now has its experimental novel. A novel of great stature, a mighty epic. Will this novel be a new starting point for other novelists? All great literature flourishes on the surface of a strong epic. It seems to me that it is not unlikely that Die Blechtrommel will open new roads in German literature and as such, will be considered as a pioneering work by later generations. ${ }^{12}$ But this evaluation only forms a very small part of his article.

In the following years Grass's name appears regularly in the Dutch papers as the best-known representative of the young German literature, invariably in combination with the title of Die Blechtrommel. However more and more, that title seems to become no more than just a mention. In 1963 De Stem, for example, published a long article on the occasion of the release of Hundejahre in Germany. Die Blechtrommel functions evidently as a point of reference for the reader, which can be seen from this perspective characteristic beginning of the article: "Anyone, who has just a faint knowledge of what is going on in world literature today, knows that Günter Grass is the man who succeeded in stirring up the complete German Federal Republic, just by publishing one single novel (...)."13 The rest of the article gives an overview of Grass's career so far, discusses his personal background and his attempt to correspond (through an open letter) with Anna Seghers on the topic of the recently built Berlin Wall. It is significant that this newspaper article wasn't written by a book reviewer or a literary expert, but by an anonymous - though well informed - journalist, who was only named as "our foreign editor".

Attention is paid in Dutch newspapers in this decade to Grass's role as a propagandist for the German Social-Democrat Party (often his personal friendship with Willy Brandt is mentioned), to the fact that eggs were thrown at Grass at a political meeting, or to the ritual burning of Die Blechtrommel by some young Protestant fundamentalists in Germany in October 1965. Although the reporting is usually of a serious nature, it always has a touch of human interest as well. For example: as the illustration next to a long article on Katz und Maus a large picture is placed of Günter Grass and his wife on their wedding day. ${ }^{14}$ To mention one more example: at the same time that Die Blechtrommel itself was barely discussed in the Dutch press, several regional

12 (Roest Crollius 1960). "Duitsland heeft thans zijn experimentele roman. Een roman van grootse allure, een machtig brok epiek. Zal deze roman voor anderen een nieuw uitgangspunt zijn? Alle grote literaturen bloeiden op de ondergrond van een sterke epiek. Het lijkt me daarom niet uitgesloten dat Die Blechtrommel aan de Duitse literatuur nieuwe wegen wijst en als zodanig, later, als een baanbrekend werk zal worden beschouwd."

13 A.P. (1963).

14 De Telegraaf, September 15, 1962. 
newspapers wrote about a publicity stunt by Grass in 1964, that had actually nothing to do with his authorship of several important literary works. The beginning of the article in question in Het Nieuwsblad van het Noorden, accompanied by a photo is typical. "Bestselling writer Günter Grass, at the moment probably the most famous representative of the young West German writers' generation in the world, recently appeared on the West-Berlin Kurfürstendamm as a newspaper seller. The 36-year-old, moustached author of prose works such as Die Blechtrommel, Hundejahre and Katz und Maus didn't undertake this rather strange, unexpected activity to earn some extra money, but to advertise loudly the local paper Spandauer Volksblatt."15 The article was entitled 'Bestselling Writer Became Paper Boy', which is an obvious allusion to the famous saying 'from paper boy to millionaire'. The title already indicates the sort of human interest article it in fact is.

The most striking example, perhaps, of the way Grass appeared in the Dutch press during these years can probably be found in the Friese Koerier, where the reviewer of Katz und Maus extensively discusses Grass's reputation as a writer, admitting that he hadn't read Die Blechtrommel at all, and that he had only heard of Grass two years earlier, because of all the fuss he caused. ${ }^{16}$

This situation of Grass becoming a public figure in the first half of the decade had two remarkable consequences. There is hardly any doubt that it must have been this quickly established fame and apparent world wide importance that led to the situation of the books after Die Blechtrommel gaining far more attention from the Dutch book reviewers than the first novel by the, at the time totally unknown, young debutant in 1959 had originally received. In particular Hundejahre was seriously reviewed by many papers and weeklies.

A second, rather paradoxical, consequence of the fast growing fame of Grass ("who has become very famous, even almost notorious, because of his Blechtrommel") was that hardly any attention was paid to the publication of the Dutch translation of the book, at the end of 1964. This translation, entitled De blikken trommel, was made by Koos Schuur. Why it took five years before the book was translated remains unclear. Grass's book had been, as we saw, a world wide success from the beginning, and the fact that it was awarded a prize for

15 Anon. (1964). "Bestseller-schrijver Günter Grass, op het moment waarschijnlijk de bekendste vertegenwoordiger van de jonge Westduitse schrijversgeneratie in de wereld, kon men onlangs op de Westberlijnse Kurfürstendamm ontmoeten als krantenverkoper. De 36-jarige besnorde auteur van prozawerken zoals Die Blechtrommel, Hundejahre en Katz und Maus ging het bij zijn vreemdsoortige bezigheid minder om de verdienste dan om een schreeuwende reclame voor de wijkkrant Spandauer Volksblatt." 
the best foreign book of the year in France, for instance, also received Dutch publicity. But the Dutch still had to wait for a translation. In one of the reviews of (the German version of) Hundejahre, the reviewer remarks, in passing, that "at last" Die Blechtrommel would be translated: "The book was published in eleven languages already, and The Netherlands will turn up as well this time."17 Did Dutch publishers hesitate for the reasons earlier mentioned by Adriaan Morriën? Namely, that it would take too much time to make a good translation, and that Dutch buyers would want to read the book in German, anyway? It is hard to say whether this is a realistic view of the capacity of the average Dutch reader. ${ }^{18}$

In terms of publicity De blikken trommel was not a success. When it was issued at the end of 1964, the translation was only mentioned in the small, specialist newspaper sections dedicated to recently published new books, with only a few lines that often referred to the international success of Grass's novel. There are only one or two texts on De blikken trommel that could be considered proper reviews. But it still remains more of a general introduction to Grass's work. A few final lines in one of them are dedicated to the translation:

The translator of this gigantic work is not to be envied, and no one is to blame that it took five years after the book appeared before the Dutch translation was published. Schuur's translating choices must occasionally be criticised. A few times he misses the right word, he has misunderstood at one point that Grass inserts loose scraps from the Catechism together and spoils its intended effect in German by placing them in a coherent context. He translates the pronoun 'das' with 'the' ('het'), and causes thereby short-circuiting, and he translates "schlägt seine Pflegerhände über dem Kopf zusammen” literally, which doesn't make any sense in Dutch etc., but on the whole he has still done a laudable translation. ${ }^{19}$

17 Grashoff (1964).

18 Although it doesn't say much about Morriën's assumption in a strict sense, an indication of the position of translated foreign literature is given by Schuyt/Taverne (2000) 456-457. It is undisputable that there is a fast increasing dominance of translated English titles on the Dutch market: where the number of English books increases from around 100 in 1946 up to over 900 in 1966, the number of translations from the German remains modest, and only increases from around 50 titles in 1946 to slightly more than 100 in 1966.

19 Maassen (1965): "Een vertaler van dit gigantische werk was bij voorbaat al niet te benijden en men mag het niemand kwalijk nemen dat nu eerst vijf jaar na het verschijnen in Duitsland, de Nederlandse vertaling is uitgekomen. Koos Schuur moet men af en toe op de vingers tikken. Hij mist een enkele keer het juiste woord, ziet op een bepaald moment 
We can safely state that Morriën's assumption that a Dutch translation of Die Blechtrommel would turn into a big economic risk has proved to be wrong. Although there are no exact figures, we can take a look at the Catalogue of the Royal Library in The Hague, to find out how many times De blikken trommel was reprinted by its publisher Meulenhoff since 1964. It turns out that Schuur's translation was reprinted 29 times, the last edition in 2008 [see appendix]. Three editions of De blikken trommel were published in the book entitled Danzig, which is the Dutch version of Die Danziger Trilogie. Although, as said before, there are no exact figures, this is an indication. On the occasion of Grass's Nobel Prize in 1999, Wil Hansen, editor at the publishing house Meulenhoff, said in an interview that De blikken trommel has always been Grass's best selling novel, and that it has kept on doing very well through the decades. He states that "several hundreds of thousands of copies were sold of the Dutch translation. ${ }^{20}$ Frank de Glas's research on Meulenhoff's history confirms that 1999 was, from an economic point of view, the most successful year for De blikken trommel. ${ }^{21}$

\section{After the Translation}

During the years after the publication of De blikken trommel the situation didn't change: still Die Blechtrommel shows up as an obvious addition when the name Grass is mentioned in any context. A rather unexpected mention is found in 1978: Oskars Blikken Trommel was the name of small restaurant in the centre of Amsterdam, named after Grass's novel by the owner who was a big admirer of the book. ${ }^{22}$ Apparently it wasn't very successful. Only one year later it was listed for sale. Ironically this was around the same time that Die Blechtrommel received a very big, new impetus because of Volker Schlöndorff's movie. As can be seen in the appendix, in the years directly following the movie's release, De blikken trommel was reprinted several times. During these years, however, Die Blechtrommel is only mentioned in the press in connection with the film, in one case with a most peculiar quotation from a review of a

niet dat Grass losse flarden uit de katechismus naast elkaar plaatst en bederft het effekt door ze in een verband te plaatsen, vertaalt het aanwijzend voornaamwoord 'das' door 'het' en veroorzaakt daardoor Kortsluiting, vertaalt "schlägt seine Pflägerhände über dem Kopf zusammen” letterlijk wat nauwelijks aanvaardbaar Nederlands oplevert enz., maar heeft over het geheel genomen toch een lovenswaardige vertaling geleverd."

20 ANP (1999).

21 De Glas (2012) 154.

22 Olof (1978). 
novel of the Dutch writer Ritzerfeld: "Ritzerfeld's descriptions reminded me of scenes from the movie Die Blechtrommel, after Günter Grass's novel." ${ }^{23}$

It took up to 1986, with the release of Die Rättin, for Die Blechtrommel to reclaim its place as a literary reference. In the years that followed, the title of Die Blechtrommel (or De blikken trommel) remains this obvious point of reference. A big stimulus - both in press mentions as well as in terms of sales (as discussed above) - was of course the Nobel Prize that was granted to Grass in 1999. Since that moment the mentions of Die Blechtrommel become almost uncountable. The classic status of the novel is undisputed in the Dutch press.

In 2009 the publisher Meulenhoff decided to celebrate the 5oth birthday of Die Blechtrommel with a brand new translation into Dutch by Jan Gielkens. Gielkens changed the novel's title into De blikken trom, which is, if we take the very first translation of Mulder into account, the third variant. A reason for Gielkens's choice is perhaps that the Dutch word 'trommel' can also refer to a box (especially one that contains small cakes: they're often made of tin), and the word 'trom' uniquely means drum. Gielkens's translation has been criticised, amongst other reasons, for this new chosen title. ${ }^{24}$

In 2014 alone, a year with no special Grass-events like jubilees or new publications, Die Blechtrommel received 40 mentions in Dutch print media. During the days after Grass's death, in April 2015, about one hundred articles were published in Dutch newspapers - both on the news pages and the literary pages and supplements. In all of them Die Blechtrommel was - more or less extensively - mentioned and discussed. And after those texts on the occasion of the author's death, the first articles have already appeared in which Die Blechtrommel (both the book and the movie) is discussed in a more general way again. Oskar's story doesn't seem to have come to an end yet in The Netherlands.

\section{Conclusions}

A few conclusions can be drawn, when we look at the way Die Blechtrommel was received in the Dutch press. A very obvious one is the strange relationship between Grass's fame as a public personality and writer of Die Blechtrommel, versus the absence of real reviews or criticisms of the book. Strictly speaking, neither Die Blechtrommel nor De blikken trommel have been reviewed in the

\footnotetext{
23 Brand (1984).

24 De Jong (2009).
} 
prevailing sense of the word. Paradoxically enough Grass's best selling novel in The Netherlands is the least reviewed one. We could confront this phenomenon with the trichotomy Dominique Maingueneau postulates in his Le Discours littéraire: he distinguishes three forms of the writer's appearance: the personne (the writer as a private person, the civil member of society), the écrivain (the writer as a writer - that is, as an actor in the literary field, and everything this means to his public appearance), and the inscripteur (the writer as the person who wrote the text, and made all the text-internal decisions). ${ }^{25}$ In the 'usual' circumstances, it seems logical that the order of appearance would be: first there is the inscripteur who writes a book, to which reviewers and all sorts of other readers respond, so that a public image emanates which is the écrivain. In the case of the reception of Die Blechtrommel in The Netherlands we see a reverse sequence: the écrivain Grass, as the writer of Die Blechtrommel existed in The Netherlands prior to the inscripteur Grass, who was initially hardly known.

Taking a look at the ideas of the reviewers, in the context of the values that are systematised by von Heydebrand and Winko, it can be concluded that there is nothing to say about the zuordnungsvoraussetzungen and appurtenant axiological and attributive values. ${ }^{26}$ This is in a way unexpected. As explained before, The Netherlands were still 'pillarised', and the Dutch newspapers had their explicit political and/or religious background. Particularly confronted with a book that is evidently political, and represents a rather outspoken world view, one would expect to find more outspoken opinions pro or contra Die Blechtrommel. But this was not the case. We see, for instance, that the article of Roest Crollius discussed above - in which he praises Die Blechtrommel as a great experimental novel - is published in De Telegraaf, a conservative populist newspaper. From this paper one would never expect any word of sympathy about a writer like Grass: and this is not even the only positive article on the German writer that has been published in this paper.

The communist daily newspaper De Waarheid matches the general practice shown above: Günter Grass's name is mentioned every now and then in his capacity as a public figure, and the first novel that was seriously reviewed was Hundejahre. In that review a political position is evident albeit rather unexpected, openly criticising the 'limited conceptions of art' that were held in the GDR.

25 Maingueneau (2004) 107-108.

26 Von Heydebrand/Winko (1996). 
The book demonstrates Grass's ambivalent attitude toward the GDR; he appreciates the anti-fascist character, but is critical with respect to the current face of the socialist part of Germany.

Unfortunately, progressive artists like Grass are not encouraged in their attitude towards the GDR, because of the limited conceptions of the art one holds there, and the negative opinion that arises from them, regarding progressive West German writers. The work of Grass is not of an accusing character. It depicts, partly with fantastic images, a German reality.

The negative aspects of the German past and present are not glossed over, but drawn without mercy to their sometimes most appalling details. Grass does not give a solution or a way out, because he does not see one himself. He is alarmed and confused.

Progressive literature from West Germany is worthy of our serious attention. The work of Günter Grass is particularly so, because it has superior literary qualities too. ${ }^{27}$

This review is the only instance in which Die Blechtrommel is mentioned in De Waarheid, until 1979, the year Schlöndorff's movie was released.

A reason why hardly any outspoken political or social comment has been given to Die Blechtrommel in the period under study might be the nature of the articles: they were not, as we have seen, personal reviews but more generally oriented journalist texts. Apart from that consideration it is in line with the findings of Esther Op de Beek in her dissertation on book reviewing in The Netherlands between 1955 and 2005. One of her conclusions is that the effects of the pillarisation have very quickly vanished from the practice of book reviewing in The Netherlands: "The average percentage of evaluations that could be

A.d.L (1965). “Uit het boek blijkt Grass' tweeslachtige houding tegenover de DDR, hij heeft waardering voor het anti-fascistische karakter, maar is kritisch ten opzichte van het actuele gezicht van het socialistische deel van Duitsland. Helaas worden vooruitstrevende kunstenaars als Grass, in hun houding tot de DDR niet bepaald gestimuleerd door de beperkte opvattingen over de kunst die men daar aanhangt en de negatieve beoordeling die er uit voortvloeit ten aanzien van deze vooruitstrevende Westduitse schrijvers. Het werk van Grass heeft niet een rechtstreeks aanklagend karakter. Het schildert, deels met fantastische beelden, een Duitse werkelijkheid. Hierin worden de kwalijke kanten van het Duitse verleden en heden niet verbloemd, of verfraaid maar onbarmhartig tot soms in hun meest stuitende details getekend. Grass geeft geen oplossing of uitweg, omdat hij die zelf niet ziet. Hij is verontrust en verward. Progressieve literatuur uit West-Duitsland is onze aandacht waard. Het werk van Günter Grass is dat in het bijzonder, omdat het tevens ongemene literaire kwaliteiten heeft." 
given the code 'political societal', 'religious' or 'moralist' review, remained low on the total number of evaluations in all survey years, and in all the papers, even in [the earliest year] 1955."28

To a certain extent the mechanism that has been detected concerning the early reception of Die Blechtrommel has remained the same throughout Grass's whole career. He regularly succeeded in gaining attention for a book even before it was translated. We see, in a different constellation of time and fame of course, in a way the same thing happen around a relatively recent novel like Grass's Im Krebsgang, where a rather distant attitude towards a literary work can be seen, particularly compared to the more committed way of reviewing we see in countries like Germany and Finland. ${ }^{29}$ The early reception of Die Blechtrommel in The Netherlands leads to the conclusion that Grass's debut novel very soon was considered a journalist news fact instead of a literary event. It wasn't until Hundejahre that a more serious view was given of Grass's books themselves. But Grass's novels never led to a real debate on political or social matters.

\section{Bibliography}

A.d.L., "De geschiedenis van de hond van Adolf Hitler. Hundejahre van Günter Grass," in De Waarheid, January 15, 1965.

Anon., "Schrijver van bestseller werd krantenverkoper," in Dagblad van het Noorden, August 29, 1964.

ANP, "Blikken trommel van Grass opnieuw bestseller," in Friesche Courant, November 27, 1999.

A.P., "Grass, belhamel en...genie, schreef onthutsende boeken," in De Stem, April 23, 1963. Boltendal, R., "Adamsappel werd een jongen tot obsessie," in De Friese Koerier, March 3 , 1962.

Brand, A., "Een heilzame wandeling over het slagveld," in Nieuwsblad van het Noorden, July 14, 1984.

De Glas, F., De regiekamer van de literatuur. Een eeuw Meulenhoff 1895-20oo (Zutphen, 2012).

De Jong, A., "Het foetert, rebbelt, bazelt en lalt; 'Grassiaanse' nieuwe vertaling van het labyrintische epos Die Blechtrommel," in NRC Handelsblad, June 26, 2009.

Grass, G., "De wijde rok' uit de roman De speelgoedtrommel" [vertaald door H. Mulder] in: Tirade, 4 (1960), Feb./March, 33-36.

$28 \quad$ Op de Beek (2014) 243.

29 Joosten (2012). 
Grashoff, P.,"Günter Grass's Hundejahre: Hond van Hitler speelt rol in kolossale roman,” in: Het vrije Volk, Juni 27, 1964.

Heydebrand R. Von, \& S. Winko, Einführung in die Wertung von Literatur (Paderborn, 1996).

Joosten, J., "Vergelijkend kritiekenonderzoek in modern Europa als (on)mogelijkheid. Een verkenning," in J. Joosten, Staande receptie: over literatuur kritiek en literatuurwetenschap (Nijmegen, 2012).

Joosten, J., "Literaire kritiek," in: M. Sanders \& T. Sintobin (eds.), Lezen in verwondering. Veertien leeswijzers bij een roman van Hugo Claus (Nijmegen, 2014), 71-88.

Maassen, J., "Günter Grass's Blikken trommel nu vertaald," in De Tijd/De Maasbode, March 29, 1965 .

Maingueneau, D., Le discours littéraire: Paratopie et scène d'énonciation (Paris, 2004).

Molin, R., “Adriaan Morriën als 'Duitslandganger', in $Z L, 1$ (2001-2002), 2 (jan 2002), $56-69$.

Morriën, A., (1999a) "Debutant die verwarring de baas blijft," in Brood op de plank. Verzameld kritisch proza I (Amsterdam, 1999), 547-550.

Morriën, A., (1999b), "H.W. Richter en zijn Gruppe," in Brood op de plank. Verzameld kritisch proza II. (Amsterdam, 1999), 621-625.

Olof, T., "Oskars Blikken Trommel," in De Telegraaf, September 2, 1978.

Op de Beek, E., Een literair fenomeen van de eerste orde. Evaluaties in de Nederlandse literaire dagbladkritiek, 1955-2005:een kwantitatieve en kwalitatieve analyse (Nijmegen, 2014).

Roest Crollius, B., "Die Blechtrommel: literaire bom ontplofte in Duitse schrijverswereld," in De Telegraaf, December 6, 1960.

Schuyt, C. and E. Taverne, 1950. Welvaart in zwart-wit (Den Haag, 2000).

\section{Appendix: Reprints of De blikken trommel}

$\begin{array}{ll}19641 & 1975 \\ 1965 & 1976 \\ 19663 & 1977 \\ 1967 & 19786 / 7 \\ 1968 & 19798 \\ 19694 & 1980 \mathbf{9} / \mathbf{1 0} / \mathbf{1 1} / \mathbf{1 2} \\ 1970 & 1981 \mathbf{1 3} \\ 1971 & 1982 \mathbf{1 4} \\ 1972 & 1983 \mathbf{1 5} \\ 1973 & 1984 \mathbf{1 6} / \mathbf{1 7} \\ 19745 & 1985\end{array}$




$\begin{array}{ll}1986 & 2001 \mathbf{2 4}+\mathbf{2 6}^{\mathbf{3 5}} \\ 1987 \mathbf{1 8} & 2002 \\ 1988 \mathbf{1 9} \mathbf{3}^{30} & 2003 \\ 1989 & 2004 \mathbf{2 8}^{36} \\ 1990 & 2005 \\ 1991 & 2006 \\ 1992 & 2007 \\ 1993 & 2008 \mathbf{2 9}^{37} \\ 1994 & 2009 \mathbf{1}^{38} \\ 1995 & 2010 \\ 1996 \mathbf{2 0 ^ { 3 1 }} & 2011 \\ 1997[\mathbf{2 1}]^{32} & 2012 \\ 1998 & 2013 \\ 1999 \mathbf{2 2}^{33} / \mathbf{2 3} & 2014 \\ 2000[2]^{34} & 20142^{38}\end{array}$

$30 \quad$ Monumenta-reeks

$31 \quad$ Rainbowpocket

32 In: Danzig [Danziger Trilogie $]$

33 Rainbowpocket

34 In: Danzig [Danziger Trilogie]

35 Aereopagus/Bibliotheek van de zoste eeuw

36 Nobelprijsbibliotheek / de Volkskrant

37 Gelegenheidsuitgave NRC Handelsblad in de reeks 'Verfilmde literatuur'.

38 Nieuwe vertaling: De blikken trom 